\title{
Surgical strategy for polydactyly of the thumb
}

\author{
Goo Hyun Baek \\ From 10th Congress of the Asia-Pacific Federation of Societies of Surgery fo the Hand and the 6th Congress \\ of Asia-Pacific Federation of Societies of Hand Therapists \\ Kuala Lumpur, Malaysia. 2-4 October 2014
}

Polydactyly of the thumb, radial polydactyly, or preaxial polydactyly is common in all races, and about 20 percent of them occur bilaterally. Patients with polydactyly of the thumb show very diverse manifestations, from a rudimentary floating type to a complex one.

The goal of surgical reconstruction is to make a straight, mobile, and stable thumb of good appearance in size and shape. The simple ablation of one digit has not produced satisfactory outcomes in most cases of polydactyly of the thumb, and resulted in retained deviation, stiffness and/or ligamentous instability of the thumb. Surgical concepts and techniques are still evolving. However, there are several reconstructive strategies to achieve a functionally and cosmetically acceptable thumb.

\section{Excision}

\section{Indication}

When an accessory thumb is attached only by a small soft tissue pedicle, or when there is no bony connection between two thumbs, simple excision of minor thumb is indicated. The dominant thumb should have good stability, motion and appearance.

\section{Reconstruction Indication}

One thumb is well developed, and the other one is less developed.

There might be bony or cartilaginous connection between two thumbs (Wassel types I, III, V), or two thumbs share a joint (Wassel types II, IV, VI, VII).

\section{Technique}

Reconstruction procedure includes arthroplasty, corrective osteotomy, and tendon realignment (Figure 1). During arthroplasty of metacarpophalangeal or interphalangeal joint, elevation of ligamentperiosteal flap is very important

$$
\text { Department of Orthopaedic Surgery, Seoul National University Hospital, }
$$$$
\text { Seoul, 110-744, Korea }
$$

\section{On-top plasty}

Indication

One thumb has well developed proximal part and poorly developed distal part (nails are frequently absent) at the phalangeal level, on the other hand, the other thumb has a poorly developed proximal part and a well developed distal part.

\section{Ray transfer}

Indication

One thumb has a well developed proximal part and a poorly developed distal part at metacarpal level, and on the other hand, the other thumb has a poorly developed proximal part of metacarpal and a well developed distal

\section{Atypical cases}

For atypical types of polydactyly of the thumb such as triplicated thumb, surgical plan should be considered individually. Some of the techniques described above 


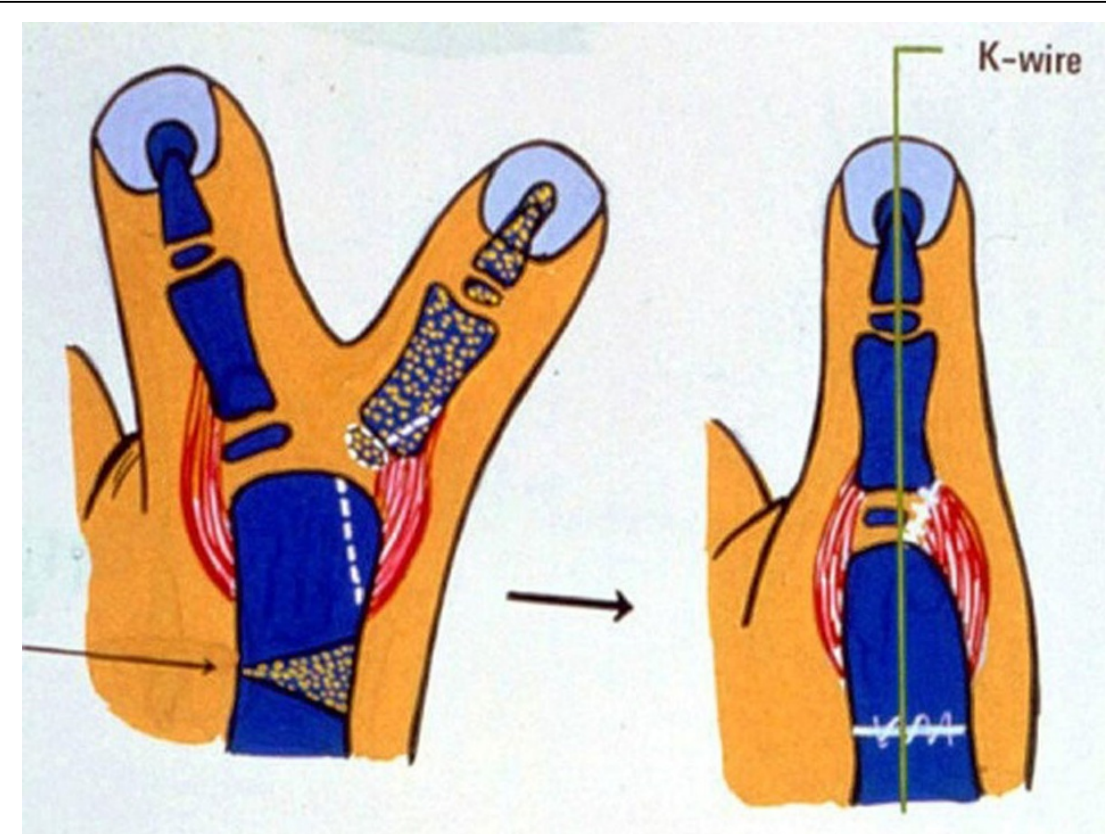

Figure 1 Ligamentoperiosteal flap was raised to reconstruct radial collateral ligament of MP joint. Metacarpal head was excised partially to fit base of dominant proximal phalanx. Corrective osteotomy was added to make a straight thumb

can be combined, and additional procedures like pollicization is needed to produce a good thumb.

Published: 19 May 2015

\section{References}

1. Baek GH, Gong HS, Chung MS, Oh JH, Lee YH, Lee SK: Modified BilhautCloquet procedure for Wassel type-II and III polydactyly of the thumb. J Bone Joint Surg Am 2007, 89(3):534-41.

2. Baek GH, Gong HS, Chung MS, Oh JH, Lee YH, Lee SK: Modified BilhautCloquet procedure for Wassel type-II and III polydactyly of the thumb. Surgical technique. J Bone Joint Surg Am 2008, 90(Suppl 2 Pt 1):74-86.

3. Tonkin MA: Thumb duplication: concepts and techniques. Clin Orthop Surg 2012, 4(1):1-17.

4. Wassel HD: The results of surgery for polydactyly of the thumb. A review. Clin Orthop Relat Res 1969, 64:175-93.

doi:10.1186/1753-6561-9-S3-A10

Cite this article as: Baek: Surgical strategy for polydactyly of the thumb. BMC Proceedings 2015 9(Suppl 3):A10.

\section{Submit your next manuscript to BioMed Central} and take full advantage of:

- Convenient online submission

- Thorough peer review

- No space constraints or color figure charges

- Immediate publication on acceptance

- Inclusion in PubMed, CAS, Scopus and Google Scholar

- Research which is freely available for redistribution 